\title{
EFFICACY OPIOIDS AND OPIOIDS-ADJUVANTS COMBINATION IN BURN PAIN TREATMENT
}

\author{
Laima Juozapavičienè ${ }^{1}$, Aurika Karbonskiené ${ }^{1}$, Rytis Rimdeika ${ }^{2}$ \\ ${ }^{1}$ Lithuanian University of Health Sciences Department of Anaesthesiology, \\ ${ }^{2}$ Lithuanian University of Health Sciences Department of Plastic and Reconstructive Surgery
}

Key words: burn pain, morphine, gabapentin.

\section{Summary}

Background. Multimodal analgesia, which employs drug combinations that have different action mechanisms in order to improve pain relief, thereby minimizing dose dependent adverse effects, is recommended for burn pain management. Effective adjuncts for analgesia for burn patients still need to be developed.

Aim: To evaluate the efficacy of gabapentin as an adjunct to morphine patient-controlled analgesia (IV-PCA) in pain treatment for burn patients during the 72 -h period after injury.

Methods. A prospective randomized controlled study. The pain treatment protocol was standardized with IV-PCA for all of the patients. The treatment patient group received $1200 \mathrm{mg}$ per day of oral gabapentin. Morphine consumption, pain scores, incidence of adverse effects were recorded every $3 \mathrm{~h}$ (during the first $24 \mathrm{~h}$ after burn) and every $6 \mathrm{~h}$ thereafter or during the adverse event cases. Pain was assessed at rest and on movement: flexion in burn of extremity and cough in burn of torso.

Results. During the study period, 53 severe burn patients (TBSA $\geq 10 \%)$ were included ( $\mathrm{n}=29$ in the control group and $n=24$ in the treatment group). Morphine consumption on the three first days after a burn was significantly lower in the treatment group than in the control group $(\mathrm{p}<0.001)$. The total morphine consumption in the treatment group was $28 \%$ less than in the control group. The VAS scores were lower in the treatment group as well $(p<0.001)$. No clinically significant adverse effects were documented.

Conclusions. Our results indicate that $1200 \mathrm{mg}$ of gabapentin may be useful as a safe analgesic adjunct in pain management for effective pain relief with an opioid sparing effect for burn patients during the 72-h period after injury.

\section{Introduction}

The pain intensity in the early phase of a burn injury is one of the most excruciating pain sensations that can be experienced [1]. Even in the acute phase of trauma, besides nociception and peripheral hyperalgesia, burn pain is also characterised by central hyperalgesia and neuropathic pain $[2,3]$. Due to large area skin nociceptor and surface fibre injury, burn patients experience acute neuropathic pain already during the first days following a burn [4]. Therefore, treatment of burn pain is a complicated task. Until today, opioids remain the gold standard in relieving strong and intolerable pain and preventing innervation of pain receptors and the wind-up phenomenon [5]. However, it is clear that they cannot ensure a full-fledged effect on all the pain formation stages $[6,7]$. Moreover, large doses of opioids are necessary to achieve satisfactory effect in the treatment of acute burn pain. The role adjuvants play in the treatment of burn pain has not been clarified up till now. Efficacy of gabapentin in the treatment of chronic neuropathic pain $[4,8]$, postoperative pain [9], pre-operative fear and anxiety [10] has been proven by scientific research and the drug is used in clinical practice, which allows making a conclusion that its inclusion into pain treatment algorithms during the shock period could be beneficial.

Our study was designed to test the hypothesis that gabapentin administration can reduce morphine consumption in patients receiving IV-PCA during the first $72 \mathrm{~h}$ post burn injury. We evaluated the pain intensity during the burn injury shock period.

\section{Methods}

The Lithuanian University of Health Sciences (former Kaunas University of Medicine) local bioethics committee 
approved the study protocol (Kaunas Regional Committee of Biomedical Research, No. BE-2-77).

The study was conducted out in Departments of Anaesthesiology and Plastic and Reconstructive Surgery, Lithuanian University of Health Sciences from March 2010 to December 2012.

This study was a prospective randomized controlled trial with a parallel-groups design. The inclusion criteria were: patients age 18 years and older, a $\geq 10 \%$ total body surface area (TBSA) burn of any depth, hospital admission on the first trauma day ( 24 hours). The exclusion criteria were: pregnancy, history of allergy to morphine or gabapentin, regular use of an analgesics for chronic pain treatment, regular use of any anti-epileptic or anti-psychotic medications, kidney and/or liver insufficiency, acute alcohol intoxication, and admission to the intensive care unit due to cardiovascular instability and/or respiratory insufficiency requiring respiratory support.

Seventy-seven patients were screened for eligibility. Six patients did not meet the inclusion criteria, five patients declined participation, and one patient had a language barrier. Overall, 65 patients agreed to participate and gave written consent. The patients were assigned by a computer-generated randomization sequence into one of the two groups: control (M) or gabapentin (G). Randomization was straight and was not adjusted according clinical status of the patient. Twelve patients did not complete the protocol and were excluded from the analysis. Twenty-nine patients in the control (M) group patients and twenty four patients in the gabapentin $(\mathrm{G})$ group patients completed the protocol, and their data were analyzed.

All patients were treated by a burn specialist and received burn injury management according to our local protocol. Morphine IV-PCA was started in all of the patients immediately after admission to the hospital. In addition, $G$ group received oral gabapentin $1200 \mathrm{mg}$ per day for three days.

PCA pumps (Perfusor fm B. Braun, B.Braun Melsungen $A G)$ were connected to each patient via a dedicated IV line or non-reflux valve. These were placed at or below the patient's heart level to avoid siphoning. The morphine concentration was standardized to $1 \mathrm{mg} / \mathrm{ml}$ in normal saline. The PCA pumps were programmed as follows: the initial dose was $2 \mathrm{mg}$ every $5 \mathrm{~min}$ (target VAS $\leq 30 \mathrm{~mm}$ ), each additional IV bolus of morphine was $1 \mathrm{mg}$ with a lockout interval of $5 \mathrm{~min}$ for the first 6 hours, and $8 \mathrm{~min}$ thereafter. The 1 hour maximum dose limits were $0.1 \mathrm{mg} / \mathrm{kg}$ for the patients who were less than 65 years of age and $0.075 \mathrm{mg} /$ $\mathrm{kg}$ for the patients who were 65 years old or above [11].

One gram of IV acetaminophen was allowed to be used as an antipyretic.

The patients were continuously monitored for cardiorespiratory function (e.g., mean arterial blood pressure, pulse rate, breathing rate, and $\mathrm{SpO}_{2}$ ), pain and sedation, as well as adverse effects, such as pruritus, nausea, vomiting, and dizziness. The follow-up data were recorded every 3 $\mathrm{h}$ (during the first $24 \mathrm{~h}$ after burn) and every $6 \mathrm{~h}$ thereafter or during the adverse event cases. Pain was assessed at rest and on movement: flexion in burn of extremity and cough in burn of torso. The first measurement was at the time of hospital admission before start of treatment $(0 \mathrm{~h})$. Pain was assessed by a $100 \mathrm{~mm}$ VAS $(0 \mathrm{~mm}=$ no pain, 100 $\mathrm{mm}=$ worst pain imaginable). A five-point sedation scale was used to evaluate and quantify sedation: 1-awake, 2-drowsy, 3-awakening by verbal stimulus, 4-awakening by physical stimulus, and 5-hardly possible to be awakened (Wilson E.) [12]. Nausea and vomiting were also registered (where 0-no nausea, 1-nausea only, 2-nausea and vomiting). Other adverse effects, such as pruritus, dizziness and visual disturbances, were scored as present or absent.

After the 72-h study period, the patients used PCA morphine as long as indicated or were treated with oral morphine.

Data collection was carried out by independent observer who was not informed about group allocation of patients.

Statistical analyses

The primary outcome measures were daily morphine consumption during the first, second and third treatment days and the cumulative morphine dose. The secondary outcome measures were pain at rest and on movement and the adverse effects. To determine the size of study groups, we performed the analysis only for the primary outcome. The sample size calculation was based on the data from our pilot study, which assumed a minimum difference of $15 \mathrm{mg}$ in the total morphine consumption. A calculation based on $\alpha=0.05$ and a power of $80 \%$ yielded a sample size of 22 patients per group using a two-tailed test. The morphine consumption, pain score, summary scores from questionnaire are summarized by presenting medians and interquartile ranges $\left(25^{\text {th }}\right.$ and $75^{\text {th }}$ percentiles $)$ of their values. The Mann Whitney U test was used to compare their values in control and gabapentin groups. Categorical data were analysed using Chi-square test and Fisher's exact test as appropriate and the results are presented as numbers and percentages. Spearman's correlation coefficient was also used, taking into account the variable distribution. Odds ratio (OR) and confidence intervals $(95 \% \mathrm{CI})$ were used to estimate the odds of the adverse effect. The difference was considered statistically significant when $\mathrm{p}<0.05$. 


\section{Results}

The two groups were homogeneous according to patient age, body mass index (BMI), burn size and type of burn, hospital admission length. There were more females in the gabapentin $(\mathrm{G})$ group. $(2=5.09, \mathrm{p}=0.024)$ (Table 1.).

\section{Morphine consumption}

Morphine consumption was significantly lower in the gabapentin group than in the control group during all three study days (day 1 , day 2 , day $3 \mathrm{p}<0.001$ ) (Figure 1). The total morphine consumption was reduced from a median of $88 \mathrm{mg}$ (interquartile range 77-104) in the control group to

Table 1. Patients' characteristics

p value - Mann-Whitney U test (age, BMI, hospital admission length) and Chi-square test (burn size, burn type, gender). Data are presented as the medians $\left(25^{\text {th }}\right.$ and $75^{\text {th }}$ percentiles), numbers and percentages. ${ }^{*}$ statistically significant $(p<0.05)$

\begin{tabular}{|c|c|c|c|}
\hline Characteristic & $\begin{array}{c}\text { Control } \\
\text { group } \\
(\mathbf{M}) \\
\mathbf{n}=\mathbf{2 9}\end{array}$ & $\begin{array}{c}\text { Gabapentin group } \\
\text { (G) } \\
\mathbf{n}=24\end{array}$ & $\begin{array}{c}p \\
\text { value }\end{array}$ \\
\hline Age (year) & $45(39.5-56.5)$ & $47(35-55.75)$ & 0.872 \\
\hline BMI $\left(\mathrm{kg} / \mathrm{m}^{2}\right)$ & $\begin{array}{c}25.51(24.34- \\
28.52)\end{array}$ & $25.57(24.02-27.38)$ & 0.657 \\
\hline Hospital admission length & $32(24-54)$ & $46.5(32.5-56)$ & 0.186 \\
\hline $\begin{array}{l}\text { Burn size } \\
<25 \% \\
25-50 \% \\
>50 \%\end{array}$ & $\begin{array}{c}13(44.8) \\
12(41.4) \\
4(13.8) \\
\end{array}$ & $\begin{array}{c}9(37) \\
14(58.3) \\
1(4.2) \\
\end{array}$ & 0.115 \\
\hline $\begin{array}{l}\text { Gender } \\
\text { Male } \\
\text { Female }\end{array}$ & $\begin{array}{c}24(82.7) \\
5(17.3)\end{array}$ & $\begin{array}{l}13(54.2) \\
11(45.8)\end{array}$ & $0.024 *$ \\
\hline $\begin{array}{l}\text { Burn type } \\
\text { Hot water } \\
\text { Flame } \\
\text { Another (chemical, } \\
\text { electrical) }\end{array}$ & $\begin{array}{c}9(31) \\
18(62.1) \\
2(6.9)\end{array}$ & $\begin{array}{c}5(20.8) \\
17(70.8) \\
2(8.3)\end{array}$ & 0.820 \\
\hline
\end{tabular}

Table 2. Incidence of adverse effects

Statistically significance $p<0.05, *$ the exact Fisher test. Data are presented as the numbers, percentages and OR (confidence intervals). ${ }^{a}$ The patients responded to oxygen therapy, no patient required naloxone administration. ${ }^{b}$ Urinary catheters were placed for monitoring fluid therapy and diuresis

\begin{tabular}{|c|c|c|c|c|}
\hline Adverse effects & $\begin{array}{c}\text { Control } \\
\text { group } \\
\text { (M) } \\
\text { n=29 } \\
\end{array}$ & $\begin{array}{c}\text { Gabapentin } \\
\text { group } \\
\text { (G) } \\
\mathbf{n = 2 4} \\
\end{array}$ & $\begin{array}{c}\text { OR } \\
\text { (Confidence } \\
\text { interval) }\end{array}$ & $\begin{array}{c}\text { Chi- } \\
\text { square p }\end{array}$ \\
\hline Desaturation $(<90 \%)^{\mathrm{a}}$ & $2(6.9)$ & $2(8.3)$ & - & 1.00 \\
\hline Nausea and vomiting & $4(13.8)$ & $2(8.3)$ & - & 0.68 \\
\hline Pruritus & $4(13.8)$ & $3(12.5)$ & - & 0.89 \\
\hline Urinary retention & 0 & 0 & - & - \\
\hline Urinary catheters ${ }^{b}$ & $19(65.5)$ & $15(62.5)$ & - & 0.76 \\
\hline \multicolumn{5}{|l|}{ Sedation } \\
\hline (2 grade episodes) & $5(17.2)$ & $12(50)$ & $4.8(1.372 ; 16.72)$ & 0.011 \\
\hline (3 grade episodes) & 0 & $4(16.7)$ & & $0.036^{*}$ \\
\hline Dizziness & $2(6.9)$ & $7(29.2)$ & $5.6(1.031 ; 24.96)$ & 0.032 \\
\hline Visual disturbances & 0 & $4(16.7)$ & - & $0.036^{*}$ \\
\hline
\end{tabular}

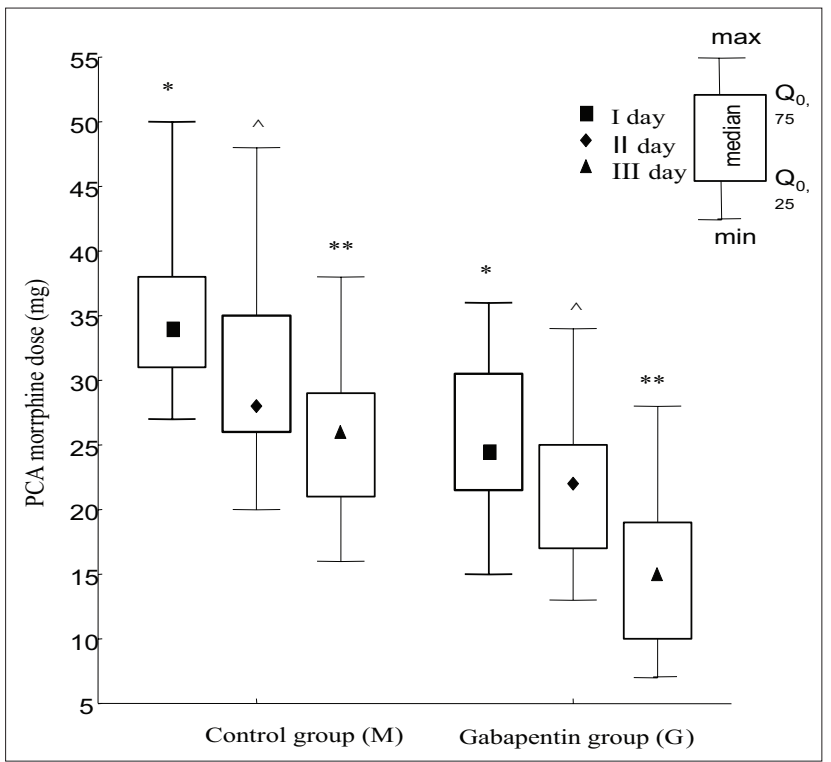

Figure 1. Morphine consumption in the control (M) and gabapentin $(\mathrm{G})$ groups during the 3 treatment days. (Median, $25^{\text {th }}$ and $75^{\text {th }}$ percentiles, $\left.{ }^{*} \mathrm{p}<0.001, \wedge \mathrm{p}<0.001,{ }^{* *} \mathrm{p}<0.001\right)$.

$63.5 \mathrm{mg}(49.5-71)$ in the gabapentin group $(\mathrm{p}<0.001)$. No rescue analgesic medication was required during the study. However, acetaminophen was given in cases of fever (temperature higher than $38.5^{\circ} \mathrm{C}$ ). Doses of acetaminophen did not differ between the groups (median value was $3(2-4) \mathrm{g}$ in group $\mathrm{M}$ and 3 (1.25-4) $\mathrm{g}$ in group $\mathrm{G}, \mathrm{p}=0.678)$.

Pain scores. Starting from 6 hours after initiating pain treatment, the patients of control group experienced more intensive pain than the gabapentin group patients at rest and on movement during the 72-h period after burn $(\mathrm{p}<0.001)$ (Figure 2).

Adverse effects. No patient required IV-PCA discontinuation due to persistent troublesome opioid-induced adverse effects. Gabapentin related adverse effects episodes, such as somnolence, dizziness, and visual disturbances, were documented in the gabapentin (G) group more often (Table 2). These adverse effects were not clinically significant and did not require disconti- 
nuation of therapy with gabapentin.

\section{Discussion}

Multimodal analgesia, which employs drug combinations that have different mechanisms of action to improve pain relief and thereby minimize the dependent adverse effects, is recommended for burn pain management. Effective adjuncts for analgesia in burn patients must be identified. Our results indicate that $1200 \mathrm{mg}$ of gabapentin may be useful as a safe analgesic adjunct in pain management for effective pain relief with an opioid sparing effect for burn patients during the 72 -h period after injury.

The efficacy of gabapentin in reducing opioid consumption has been documented in hysterectomy [13], spinal surgery [14], after mastectomy and breast surgery [15], and knee arthroplasty cases [16]. Several meta-analyses and systematic reviews have demonstrated the efficacy and safety of preoperative gabapentin in multimodal pain management $[17,18]$.

Rimaz $\mathrm{S}$ et al. found that a single preoperative dose of $1200 \mathrm{mg}$ of gabapentin as an adjunct to morphine analgesia decreased the total postoperative morphine consumption and postoperative pain scores at rest and on movement after burn wound
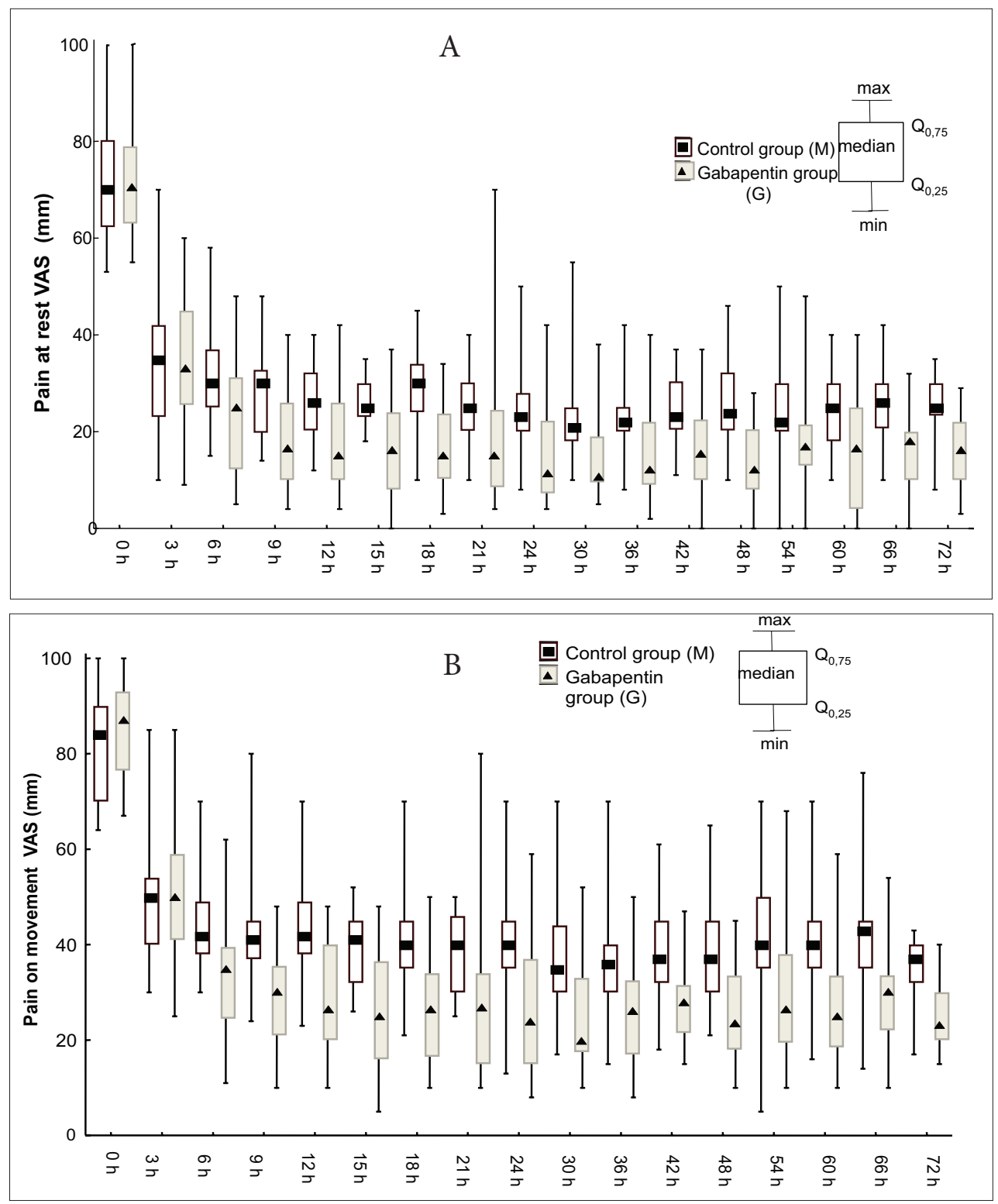

Figure 2. Pain intensity at rest (A) and on movement (B) during every 3 h (first day after burn) and 6 $\mathrm{h}$ (second and third treatment day) of follow-up.

Panel A: at rest $p=0,88$ and $p=0,377$ at $0 \mathrm{~h}$ and $3 \mathrm{~h}$, respectively, $\mathrm{p}<0,001$ at $6-72 \mathrm{~h}$.

Panel B: on movement $p=0.768$ and $p=0.302$ at $0 \mathrm{~h}$ and $3 \mathrm{~h}$, respectively, $\mathrm{p}<0.001$ at $6-72 \mathrm{~h}$.

debridement [19]. In an observational study by Cuinet et al., an opioid-sparing effect of gabapentin was reported. A daily oral dose of $2400 \mathrm{mg}$ of gabapentin for 21 days, starting on the $3^{\text {rd }}$ post-burn day (i.e., following the shock phase) reduced the opioid requirements in burn patients [3]. Our results are in line with these two studies despite a different study design.

However, our results differ from reported by Wibbenmeyer L et al. [20], who were unable to show a reduction in opioid consumption with gabapentin administration during the 
acute burn injury period. The daily opioid requirements did not differ between the groups; but the study protocol had substantial differences, including burn sizes that were greater than $5 \%$ of the total body surface area and a study drug titration schedule that consisted of $1200 \mathrm{mg}$ of gabapentin on the first study day and $300 \mathrm{mg}$ thrice daily $(900 \mathrm{mg}$ ) on study days 2 and 3. It is clear that the administration of gabapentin in conjunction with systemic analgesia requires further investigation with respect to the timing and duration of administration.

We found that the pain intensity both at rest and on movement was not significantly different between the groups at the 0 - and 3-h follow-up period. After a single oral dose of gabapentin, the mean maximum plasma concentration is

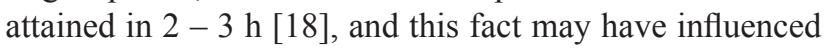
this result.

Pain has a mainly nociceptive character in the acute burn injury period. Peripheral hyperalgesia, central hyperalgesia, and neuropathic pain are also important pain components $[3,4,21]$ in this period. The burn injury damages and partially destroys nerve structures. According to this fact, neuropathic pain can occur directly or after a period of time [5]. A Gray P et al. demonstrated that neuropathic pain was detected within 1 to 7 days after a burn injury [4].

The dose-dependent adverse effects of opioids may interfere with the analgesia plan and may lead to a reduced quality of pain relief. Respiratory depression, which is the most important side effect of morphine PCA, may be more common when a background infusion is added [11]. We did not use a background infusion and no patient required naloxone for respiratory depression. Many studies with gabapentin report common side effects, such as somnolence, dizziness, and visual disturbances $[18,22]$. The use of higher dose of gabapentin increased the incidence of adverse effects [23]. Sedation is frequent during acute pain treatment with gabapentin according to a meta-analysis by Ho $\mathrm{K}$ et al. [24]. Our study results regarding sedation are similar. The dizziness and visual disturbance incidences were comparable with results from other studies [18, 22]. No patient in our study withdrew due to adverse effects. The present study did not find any serious adverse events that would limit the use of $1200 \mathrm{mg}$ gabapentin in burn pain treatment during shock period.

It is important to acknowledge the limitations of the present study. First, although this trial was randomised, however not double blinded. Second, our study was limited by its short therapeutic intervention duration. The gabapentin effects were monitored only for a 72-h period after injury. Admittedly, burn treatment and continuous pain lasts much longer. Moreover, therapeutic procedures, such as dressing changes and burn wound debridement, induce additional pain episodes that might contribute to the causality between acute and chronic burn pain.

\section{Conclusions}

Our study shows that gabapentin is a safe and effective adjunct in multimodal pain management in the shock period for burn patients. An opioid-sparing effect and reduce pain intensity scores were documented.

\section{References}

1. Montgomery RK. Pain Management in burn injury. Critical Care Nurs Clin North Am 2004;16:39-49.

2. Summer GJ, Puntillo KA, Miaskowski Ch, Green GP, Levine JD. Burn injury pain: The continuing challenge. The Journal of Pain 2007;7(8):533-548.

3. Cuinet O, Pirson J, Soudon O, Zizi M. Effects of gabapentin on morphine consumption and pain in severely burned patiens. Burns 2007;33:81-86.

4. Gray P, Williams B, Cramond T. Successful use of Gabapentin in acute pain management following burn injury: a case series. Pain Medicine 2008; 9(3):371-376.

5. Jeschke MG, Kamolz LP, Sjoberg F, Wolf SE. Handbook of Burns. Acute Burn Care. Pain Management after burn trauma. Springer - Verlag Wien 2012; 338-360. ISBN 978-3-70910347-0 Springer Wien New York.

6. Laycock H, Valente J, Bantel C, Nagy I. Peripheral mechanisms of burn injury - associated pain. European Journal of Pharmacology 2013;716:169-178.

7. Sullivan S, Friedrich JB, Engrav L, et al. "Opioid creep" is real and may the cause of "fluid creep". Burns 2004;30:583-590.

8. Cheng JK, Chiou LCh. Mechanisms of the antinociceptive action of gabapentin. Journal of Pharmacological Sciences 2006;100:471-486.

9. Mathiesen O, Moiniche S, Dahl BJ. Gabapentin and postoperative pain:a qualitative and quantitative systematic review, with focus on procedure. BMC Anesthesiology 2007; 7(6). http:// biomedcentral.com/1471-2253/7/6

10. Clarke H, Kirkham KR, Orser BA, Katznelson R, Mitsakalus N, Ko R, Snyman A, Ma M, Katz J. Gabapentin reduces preoperative anxiety and pain catastrophizing in higly anxious patients prior to major surgery: a blinded randomized placebocontrolled trial. Can Journal Anesth 2013:60(5):432-43.

11. Cheung ChW, Ying AL, Lee HY, Tsang SF, Tsui SL, Irwin MG. An audit of postoperative intravenous patient - controlled analgesia with morphine: Evolution over the last decade. European Journal of Pain 2009;13:464-471.

12. Wilson E, David A, Mackenzie N, Grant IS. Sedation during spinal anaesthesia: comparison of propofol and midazolam British Journal of Anaesthesia 1990;64:48-52.

13. Dierking G, Duedahl TH, Rasmussen ML. et al. Effects of gabapentin on postoperative morphine consumption and pain 
after abdominal hysterectomy: randomized, double-blind trial. Acta Anaesthesiol Scand 2004;48:322-7.

14. Pandey CK, Sahay S, Gupta D. et al. Preemtive gabapentin decreases postoperative pain after lumbar discectomy. Can J Anaesth 2004;51:986-9.

15. Fassoulaki A, Triga A, Melemeni A, Sarantopoulos C. Multimodal analgesia with gabapentin and local anesthetics prevents acute and chronic pain after breast surgery for cancer. Anesth Analg 2005;101:1427-32.

16. Clarke H, Pereira S, Kennedy D, Gilron I. Gabapentin decreases morphine consumption and improves functional recovery following total knee arthroplasty. Pain Res Manage 2009;14(3):217-222.

17. Seib RK, Paul JE. Preoperative gabapentin for postoperative analgesia: A meta-analysis. Can J Anaesth 2006;53:461-9.

18. Tiippana EM, Hamunen K, Kontinen VK, Kalso E. Do surgical patients benefit from perioperative gabapentin/pregabalin? A systematic review of efficacy and safety. Anesth Analg 2007;104(6):1545-56.

19. Rimaz S, Alavi CE, Sedighnejad A. et al. Effects of gabapentin on morphine consumption and pain after surgical debridment of burn wounds: a double-blind randomized clinical trial study. Archives of Trauma 2012; 1(1):38-43.

20. Wibbenmeyer L, Eid A, Liao J, Heard J, Horsfield A, Kral L, Kealey P, Rosenquist R. Gabapentin is Ineffective as an Analgesic Adjunct in the Immediate Postburn Period. Journal Burn Care Res 2014; 35(2):136-42.

21. Gray P, Kirby J, Smith TM, Cabot JP, Williams B, J Doecke J, Cramond T. Pregabalin in severe burn injury pain: A doubleblind, randomised placebo-controlled trial. Pain 2011;152: 1279-1288.

22. Peng PW, Wijeysundera DN, Li CC. Use of gabapentin for perioperative pain control - a meta-analysis. Pain Res Manage 2007; 12:85-92.

23. Clivatti J, Sakata RK, Issy AM. Review of the use of gabapentin in the control of postoperative pain. Rev Bras Anestesiol 2009;59:1:87-98.

24. Ho KY, Gan TJ, Habib AS. Gabapentin and postoperative pain - a systematic review of randomized controlled trials. Pain 2006;126:91-101.
OPIOIDŲ BEI OPIOIDŲ IR ADJUVANTŲ DERINIO VEIKSMINGUMAS GYDANT NUDEGIMO SKAUSMĄ

\section{Juozapavičienė, A. Karbonskienė, R. Rimdeika}

Raktažodžiai: nudegimo skausmas, morfinas, gabapentinas.

Santrauka

Ivadas. Nudegusiems pacientams tinkama daugiaveiksnè analgezija, derinant skirtingas grandis veikiančius analgetikus nulemtų veiksmingesni skausmo gydymą, kartu sumažintų nuo dozès priklausomų šalutinių poveikių dažnį. Ieškoma efektyvių adjuvantu, papildančiu analgezijos derinius, gydant nudegimo sukeltą skausmą.

Tikslas. Ivertinti adjuvanto gabapentino veiksmingumą, gydant nudegimo skausmą morfino infuzija paciento kontroliuojamos analgezijos (PKA) metodu pirmas 72 val. po nudegimo.

Metodika. Atliktas perspektyvusis atsitiktinių imčių klinikinis tyrimas. Visi tyrime dalyvavę pacientai gydyti paciento kontroliuojama analgezija morfinu. Gabapentino $(\mathrm{G})$ grupès pacientai gavo $1200 \mathrm{mg}$ gabapentino per dieną. Morfino suvartojimas, skausmo intensyvumas, analgezijai skiriamų šalutiniai vaistų poveikiai stebèti ir registruoti kas tris valandas pirmąą parą po nudegimo, antrą ir trečią tyrimo dienas duomenys registruoti kas 6 val. Skausmo intensyvumas vertintas ramybeje ir judant.

Rezultatai. Tyrime dalyvavo 53 pacientai, nudegę daugiau kaip 10 proc. kūno paviršiaus ploto (kontrolinèje grupeje $n=29$ ir gabapentino grupeje $n=24)$. Morfino suvartojimas visas tris tyrimo dienas reikšmingai mažesnis gabapentino grupejje nei kontrolinèje grupèje $(\mathrm{p}<0,001)$. Suminè morfino dozè gabapentino grupèje 28 proc. mažesnè lyginant su kontroline grupe. Žemesni skausmo intensyvumo balai nustatyti gabapentino grupeje $(p<0,001)$. Kliniškai reikšmingų šalutinių vaistų poveikių nenustatyta.

Išvada. Mūsų tyrimo rezultatai parodè, kad gabapentinas yra saugus ir efektyvus adjuvantas, gydant nudegimo sukeltą skausmą. $1200 \mathrm{mg}$ gabapentino reikšmingai sumažino opioidų dozę ir skausmo intensyvumą nudegusiems pacientams pirmas 72 val. po nudegimo.

Adresas susirašinėti: laima.juozapaviciene@gmail.com

Gauta 2015-04-08 